\title{
Policy conclusions: on the future of European employment
}

Citation for published version (APA):

Petit, P., \& Soete, L. L. G. (2001). Policy conclusions: on the future of European employment. In P. Petit, \& L. Soete (Eds.), Technology and the Future European Employment (pp. 507-540). Edward Elgar Publishing. https://doi.org/10.4337/9781781950999.00028

Document status and date:

Published: 01/01/2001

DOI:

10.4337/9781781950999.00028

Document Version:

Publisher's PDF, also known as Version of record

\section{Please check the document version of this publication:}

- A submitted manuscript is the version of the article upon submission and before peer-review. There can be important differences between the submitted version and the official published version of record.

People interested in the research are advised to contact the author for the final version of the publication, or visit the DOI to the publisher's website.

- The final author version and the galley proof are versions of the publication after peer review.

- The final published version features the final layout of the paper including the volume, issue and page numbers.

Link to publication

\footnotetext{
General rights rights.

- You may freely distribute the URL identifying the publication in the public portal. please follow below link for the End User Agreement:

www.umlib.nl/taverne-license

Take down policy

If you believe that this document breaches copyright please contact us at:

repository@maastrichtuniversity.nl

providing details and we will investigate your claim.
}

Copyright and moral rights for the publications made accessible in the public portal are retained by the authors and/or other copyright owners and it is a condition of accessing publications that users recognise and abide by the legal requirements associated with these

- Users may download and print one copy of any publication from the public portal for the purpose of private study or research.

- You may not further distribute the material or use it for any profit-making activity or commercial gain

If the publication is distributed under the terms of Article $25 \mathrm{fa}$ of the Dutch Copyright Act, indicated by the "Taverne" license above, 


\section{Policy conclusions: on the future of European employment}

\section{Pascal Petit and Luc Soete}

The overview of the contemporary aspects of technical change and their implications for employment growth and displacement - what we described in our introduction as the employment dynamics - presented in this book reveals at first sight some grim features for Europe. On the surface, the diversity of institutions and experiences appears to have limited the chances for Europe to gather endogenously its own growth momentum and propel it along an autonomous expansion path. The same diversity appears also to have seriously hampered Europe's reaction to external changes, whether on product, skilled labour or financial markets, or in the development and commercialization of new technologies. Yet it is obvious that diversity may also have its advantages. It might lead to more creative responses to external challenges and help in fostering new, different, possibly promising, endogenous developments. And Europe has of course undergone changes in all its dimensions and components over the last two decades. Many of these have barely had their full impact yet on European society and on the many, very different economic, social and cultural nations and regions of which it is composed.

In this concluding chapter, we provide some further insights where the findings of the research brought together in this book might help one to strike a balance between the advantages and disadvantages of such an evolving Europe. From this perspective, great care must be taken in assessing the time horizons and time lags that are implicit in discussing any prospective view. A first, in our view, essential, consideration is that, behind the diversity of the various European countries' performance at both the technology and employment levels, one finds different evolution processes, implying different kinds of learning, of time horizons and time lags.

We start by looking briefly at some of the major institutional changes likely to influence the dynamics of employment in the European member countries in the following decades. This assessment illustrates how different the last two decades have been compared to the earlier postwar period and 
highlights the kinds of institutional changes which successively played a dominant role, whether one considers the field of labour markets and job creation or of financial markets. We then turn to an appraisal of the organizational and structural changes in Europe. Without trying to be exhaustive, we shall stress the main lines of development regarding changes in organization within firms, as well as between them. Our analysis will focus on the reactions of firms with respect to the development, diffusion and use of new technologies, but will also pay special attention to sectoral changes where the expansion of services has played and continues to play a major role, redefining the conditions under which economic transactions emerge and are becoming commercialized. Finally, we shall come back to the dynamics of growth and employment, taking into account the demographic and societal factors which are likely to shape Europe's future.

The discussion of these various issues is organized in reverse order to the one followed in the four parts of this book. In this way, we hope to re-enforce somehow the aspect of a 'balance sheet' of past developments at different levels: institutions, firms, sectors and, finally, countries which can lead us to draw some broader analytical policy conclusions which might further or counter some of the trends identified.

\section{INSTITUTIONAL CHANGES IN LABOUR MARKETS: FROM LABOUR MARKET FLEXIBILITY TO EDUCATION AND TRAINING ISSUES}

Institutional changes are continuing processes which change pace, accelerate or bifurcate in times of crises, as when situations in important spheres of activities appear to be unsustainable. Crises may of course be of various magnitude and coverage. The strong inflation and mass unemployment which successively developed in the late 1970 s and early 1980 s were from this perspective symptoms signalling and ultimately characterizing the period as a phase of economic crisis. The institutional changes of the 1980 s were motivated by the need to get out of this crisis. They led to structural adjustments - a key phrase in the $1980 \mathrm{~s}$ - aimed at reforming labour market institutions. Increasing the flexibility of labour markets became a widespread policy objective. A second field of reform, more typical of the late 1980s, was brought about by a more general concern not only to control wage inflation but more generally to expand the sphere of 'deregulated' market activities in order to take advantage of internationalization and the potential of information and communication technologies which modified the time and space dimensions of economic activities.

The 1980s were for all developed countries still an early phase in the diffusion of the new technological system centred upon the new technologies 
of information and communication. Still some countries were in advance and some lagged behind (see, for example, the spread in the ratios of ICT investment expenditures to GDP over the 1980s, compared to the more recent period: OECD, 1999). The growing internationalization of most developed economies was on its way and international competitiveness was thought to depend strongly on the mastering of these new technologies. Countries, conscious of going through a period of transition, Jaunched under different conditions and with different strength and emphasis these two waves of reforms and institutional changes concerning the large intermediation services and the adjustment of labour markets. While deregulation of 'regulated' services appeared to be a worldwide phenomenon, which started in the early 1980s in the USA and spread progressively through the decade to the whole developed world, the need for the deregulation of labour markets concerned more especially Europe.

The notion of European sclerosis developed in the early 1980s to take into account the continuous rise in unemployment in Europe. This characterization was a partial view, omitting to take into account the quality of the jobs created and the overall rates of employment (and in particular the shares of age groups in the workforce) which themselves reflected different life styles and traditions. Still the debate in itself echoed a widespread pressure to reform labour markets. And indeed, although blaming rigid labour markets was often exaggerated and critics did not take into account the effective capability of labour markets to adjust, most European countries reformed their rules and practices towards more flexibility to short-run changes in product markets and to new patterns of organization (both within firms and across firms). In all these cases the change in the sectoral structure of employment did facilitate such transformation. The expansion of service activities, much less institutionalized than manufacturing activities on average, did help to create more flexible labour markets. This major, continuing change in the structure of employment was all the more open to all kinds of new forms of work organization as the large service activities, where labour was more organized and where more rigid practices constrained the organization of work, were under the strain of deregulation and the ensuing rearrangement of their production processes. Clearly, by the end of the 1980 s, flexibility of the labour markets was no longer a major issue on the policy agenda - despite the popularity of international organizations' studies, such as the OECD Jobs Study addressing national unemployment and job creation issues (OECD, 1995a) - and the debate shifted more towards participation rates, hife styles and new forms of socialization.

The debates about work, non-work and the status of work really only started during this last decade. While many of the concepts used are reminiscent of the 1960s, these debates are new and in the end do not replicate those 
of the aftermath of World War II, as most rich OECD societies in which they are taking place are now much more often composed of double-income families, living mostly in urban areas and nearly three-quarters of them occupying jobs in services. The old debates and the choices made in the postwar period, especially regarding the type of welfare states, do influence today's options, but the societies are more affluent and more educated. Therefore the issues involved in redefining the status and content of work over each person's individual life cycle are now more centred upon the kinds of training, the types of family structures preferred, the borders between public and private, personal and collective, as well as on the division between work and non-work activities over one's life cycle.

Lars Mjøset in his contribution stressed how pregnant are the various types of welfare states in current debates and ultimately choices of the individual European countries. The fact is that evolutions of welfare states occur in rather marginal and incremental ways, generally speaking by means of small discrete adjustments of primarily national systems which have evolved around some central options made five decades ago (themselves more or less rooted in long pasts) regarding, first, the role of the family in securing welfare and the relative place of the young and old generations, and second, the ways by which to finance social welfare coverage.

In effect, the relative continuity of these evolutions is worth underlining. One may also observe that these issues are far less often debated than they deserve in the political spheres of the various countries at the level of large societal choices that they imply. We would agree with Heilbroner and Milberg (1995) that there is a certain lack of vision in the political debates of our societies when addressing these basic issues. Four decades of macroeconomic national policy have to some extent paid the price and restricted most policy debates to broad macroeconomic objectives such as the reduction of inflation, the fight against unemployment and the fostering of economic growth. When these objectives began to appear out of reach of national policy makers, at least in the short run, the political debates failed to reformulate new policy objectives in broad, yet still concrete, terms of societal choices. In smaller countries (the Scandinavian countries, the Benelux, Ireland) where the limits of national policy actions were recognized much earlier, such debates took place to a much greater extent.

The debate about the reduction in working time is very indicative of such reductionism. In societies where the status of wage earner has become strongly predominant, the debate tends to be mainly concerned with the reorganization of work and much less with the reorganization of non-working time. Again the evolution of working time across countries does show that, beyond a common trend of reduction in working time, the patterns remain quite different. Countries combine in various ways flat reductions in working time 
across the board of all occupations with expansions in part-time work, as stressed in the contribution by Spiezia and Vivarelli in Chapter 13. This leads to two polar cases, one experiencing modest decreases in average working time and an uneven distribution of part-time work (close to the UK and the US experiences) and another experiencing a substantial decrease in average working time with a more even distribution of part-time work (more in line with the experiences of continental Europe countries such as France and Germany). To go further in the reduction of working time, reducing either the average working time in all occupations or increasing the diffusion of parttime work in all activities, clearly depends on whether it is voluntary and seen as improving welfare or imposed and seen as constrained by what is perceived as a scarcity of available jobs. Again the answer depends on the overall social project in which such arrangements are taking place. To reconstruct an effective macroeconomic policy one is therefore forced to debate also some of the fundamental options which our societies are being confronted with concerning life styles, education and training, environment and social cohesion.

What should be the role of education and training is certainly part of these interrogations, but again one has to allow for the new context in which the supply of qualified labour has been substantially enlarged and the use of knowledge in economic activities extended, be it in codified or tacit forms. Again these debates about the role of education and training may be too much oriented by a vision centred upon production processes, and not taking into account personal needs and well-being. Thus, following the debates in the economics literature, the issue of education and training has to focus on both the increase in the demand for skilled labour and the abundance of the supply of qualified labour, both shifts inducing changes in the effective role of training and education. Both phenomena obviously have their share in explaining the increase in skill and, more generally, knowledge intensity in society. On one side, the debate about the presumed 'skill-biased' nature of technological change emphasized the fact that firms upgraded their skill requirements in order to face uncertainty in the evolution of productive processes in times of rapid technological change and tense competition (once the direct effect of the trade with low-wage countries has been scaled down to its relatively minor dimension: see Petit and Soete, 1997, for a short survey of this issue). On the other side, studies have stressed that the supply of qualified labour had largely increased all over the developed world, to such an extent that in some countries it has in itself reduced the number of jobs for the so-called 'non-qualified' (Goux and Maurin, 1996; OECD, 1996a, ch. 4).

By contrast, very little has been said about two other major dimensions of the new challenge to education and training. One has to do with the social value of education and training, not only for participation in traditional social 
networks (conditioning, amongst other things, family structuring and job opportunities) but also for gaining access to new life patterns and taking advantage of complex new service provisions (not only in health and education but also in finance, transport, communication and distribution). From this perspective education and training has also to respond to new needs in economies in which relationships between users and producers have become essential knowledge links, with 'smart' consumers as the final link. The other major dimension has to do with the laws of obsolescence of knowledge brought about by education and training. Recent work on literacy (OECD, 1997) shows that the rate of obsolescence, as measured in comparing the effective capabilities of various education levels after some years, varied strongly among countries.

These two issues raise questions about the content of education and training, the forms and channels for its provision and its timing along the life cycle. These questions are rather different from the ones raised in the postwar era, where educational systems provided initial training of different kinds, giving access to specific professional trajectories determined from the start, more or less rigidly, across countries. The advantages brought by education remain effective but more widespread and open to various upgrading and downgrading hazards encountered on the job. It follows that the meritocratic model, whereby positions were gained according to the years of education, may not work as systematically and steadily as before. Rates of return may vary strongly for the same degree or course and it is not that easy to determine which study curriculum to follow - especially as careers not only correspond to a wide range of wages trajectories but also include, increasingly, non-wage incomes (such as stock options or standard financial benefits).

As a matter of fact, in the new economic environment of the 1990s, the question of wages and incentives has gained dramatically in importance. Many practical ways of alleviating the fiscal levy on the highest incomes, developing new schemes of profit sharing and of wage funds, as well as reducing minimum wages and therefore reducing their impact, were developed in individual countries. Development of various forms of pension funds can be seen from the same perspective of restructuring distribution, not so much to ensure solidarity between wage earners (as has been the case in the past) or to increase flexibility of labour markets - an objective sufficiently attained by the late 1980s - but to stimulate incentives for individuals whose personal response and degree of competence seemed to condition the success of the new productive processes.

Both issues of training and incentives are from this perspective central in the actual processes of institutional and organizational change. It still is a phase of complex and substantial trials and errors, as economies are facing new situations where the challenges are no longer to fight shortages of 
collectively defined qualified labour, but to provide and put to use individual competences (see also Vendramin and Valenduc, 1999). It is important to stress the greater individualization implied in this process and the ensuing difficulty of promoting social norms of training for the provision of competences which in the end rely on combinations of formal training and experiences at work and out of work.

We would thus conclude by arguing that a new approach to education, training and incentives must be high on the policy agenda, while the debate about the 'desired' level of flexibility of labour markets, insofar as it had already been more or less reached by the end of the 1980s, might well be moved to a somewhat lower level. Such a shift in policy priority setting is actually in accordance with the trend towards a more knowledge-based economy. As we mentioned before, this trend is prone to favouring, at least in a first phase, unequal access to new forms of jobs and new consumption patterns. This diffusion process seems also bound to increase inequalities in wage formation. In various ways the development of banking and finance services as well as the reorganization of large networks services, which we discuss next, are instrumental in fostering such new economic trends.

\section{INSTITUTIONAL CHANGES IN FINANCE AND INTERMEDIATION SERVICES: FROM DEREGULATION TO THE ASSESSMENT OF NEW PRIORITIES}

The deregulation of large network services has been a major development of the late 1980s and 1990s. It started with the financial sector with obvious important consequences for the global functioning of the developed and, more recently, industrializing countries and the economies in transition. Financial sectors were highly and diversely regulated from the 1930s and 1940s. In the 1970s, while international transactions had entered a new, postBretton Woods era, the national restrictions were in danger of either being effectively bypassed or blocking the international dynamics of products markets. Deregulation was slow and partial, depending on the initial situation in the various countries. Progressively, and in very different forms among countries, financial capital acquired a new mobility and creativity. It transformed the governance in all activities, on the one hand giving more importance to short-run transparency and profitability and, on the other, heiping to finance risky but highly profitable longer-term projects.

By and large, European countries followed in a very diverse fashion the deregulation path taken by the USA. They were in very different positions to do so, depending on the characteristics of their own financial systems. Crucial in 
that respect were the different national ways in which firms and households financed their projects: for firms, the different ways they financed their investments in the first place, but also their merger and acquisition attempts or their temporary needs for liquidity; for households, how they financed their consumption and investment (of which housing was in most countries the most important component) but also how they saved income for the future, an issue which, as we saw above, makes a big difference for the operation and financial sustainability of welfare states - whether capital is being accumulated, as in the case of pension funds, or whether those currently at work pay the pensions and welfare contributions of those not at work. In both cases external changes, like structural changes in financial markets or in demographic structure, strongly challenge the viability of the systems.

Systems were so different that the deregulation move of the late 1980s did not lead to any real convergence of the systems (on 'national systems for financing innovation', see OECD, 1995b). Still the widespread deregulation moves induced some common trends. For firms, financial markets became a more important means for developing an enlarged range of operations. Banks increased their global reach in developing international networks and linkages. Many more risky projects, most of them innovation projects in a broad sense, could be financed. For households and individuals, new forms of savings developed, especially by means of a larger use of financial markets, whether directly through buying stocks - people capitalism - or indirectly through pension schemes, not to mention much easier forms and management of payments.

This again led to large discrepancies between firms (not only by size and financial strength but also by limited know-how in using the new banking and finance system) but also to discrepancies between individuals (not only in the relative importance of financial gains in their current income but also in their abilities to use the facilities of the system). These discrepancies brought to the forefront, bowever, the general nature of the move. While the old system had been stressing the principle of universal service through which access was universally guaranteed and every user was in a position to fulfil his basic 'needs' regarding loans and savings as well as payments, the new systems provided a much wider range of services and the issue now became 'prudential', for example in order to make clear the rules under which the systems and services were operating. This concern over the 'transparency' of the services provided is far-reaching and not so easy to solve or calibrate, as it implies knowledge about the capabilities of the users. In this sense, the financial deregulation move is an integral part of the diffusion of a new economy.

What is so clearly identifiable in the case of the financial sectors can also be detected and observed in relation to the evolution of the other large network services which play a role of intermediation in the working of 
markets such as the communication, transport or distribution sectors. These issues are largely stressed in Chapter 6, which emphasizes the fact that the new technologies of information and communication deeply transformed these activities of intermediation. In effect, the deregulation of these sectors again followed more or less rapidly that of the banking sector under rather similar external pressures, with the added feature that not only were a large proportion of these activities highly regulated but also they were provided by public bodies (whatever their exact status). Privatization thus took more time on average and went through a longer transition period. Telecommunication services give a good example of both the length of time necessary to privatize large, highly profitable, national public enterprises (as in France or in Germany) and the long period of transition it takes for the new structure to adjust to market forces and ongoing technological changes (as became obvious from the earlier transformation of the telecommunications sectors in the USA and in the UK). It follows that, by the end of the 1990s, operators and market regulations still had a long way to go from the old regulatory context to the one which is more likely to prevail in the future. Still the issues are rather similar to the ones mentioned in the case of finance, with the same shift away from universal access, and the existence of discriminations and barriers constituted by differences in know-how and knowledge on the user's side and the same 'prudential' principle of transparency (and privacy) regarding the rules and contents of the services provided.

This state of broad institutional change conditions in different ways the evolution of the various national systems of innovation, as we shall outline below. But the trends accompanied and favoured over the last two decades by the institutional changes in labour markets and financial markets have also had a noticeable effect in terms of prices and distribution. On the one hand, the achievement of a certain level of labour market flexibility helped to get rid, at least partially, of any basic wage inflation pressure; on the other, the reorganization of financial markets appears to have led to some structural inflation pressure of financial assets (of which the unprecedented steady growth of stock market indices is a major sign). The feature may not be so clear-cut. Some financial assets may experience clear downswings or falls (there is of course no indexation of financial assets, as in the case of wages) and wages of some professionals may enjoy long-lasting upswings, as experienced with the salaries of CEOs, most of the time enlarged by stock options. Still the 1990 s and the years to come offer a clear, new picture which also changes the context in which technologies are diffusing, innovations are made and employment is created.

Table 16.1 summarizes what we have just outlined regarding the main directions of institutional changes as they appeared to emerge in the developed economies over the last two decades. 
Table 16.1 Key issues in the institutional changes of the 1980s and 1990s

\begin{tabular}{cll}
\hline & 1980s & $1990 \mathrm{~s}$ \\
\hline $\begin{array}{c}\text { Labour markets and } \\
\text { educational systems }\end{array}$ & $\begin{array}{l}\text { Flexibility of labour } \\
\text { markets and quantity } \\
\text { adjustments of } \\
\text { educational systems } \\
\text { Disindexation of wages }\end{array}$ & $\begin{array}{l}\text { Quality adjustment of } \\
\text { education and training, } \\
\text { selective adjustment of } \\
\text { wage and income } \\
\text { formation }\end{array}$ \\
$\begin{array}{cll}\text { Financial markets } \\
\text { and banking systems }\end{array}$ & $\begin{array}{l}\text { Deregulation of finance } \\
\text { industries }\end{array}$ & $\begin{array}{l}\text { Development of } \\
\text { 'prudential' rules and } \\
\text { selective risk coverage } \\
\text { procedures } \\
\text { Limited regulation of } \\
\text { international financial } \\
\text { flows }\end{array}$ \\
& &
\end{tabular}

\section{NATIONAL SYSTEMS OF INNOVATION AND THE NEW TECHNOLOGICAL PARADIGM: A PROCESS OF INTERNATIONALIZATION}

The evolution of the wage-labour nexus and of the financing conditions, discussed in the two previous sections, has had a direct influence on the diffusion of the new technological system centred on new information and communication technologies. In the first place, as we have already underlined, the institutional changes in the late 1980s and 1990s were in line with the emergence of a new economy where individual knowledge was more directly in a reactive and creative interaction with all kinds of codified knowledge embodied in equipment and organizations. Knowledge management and capital risk financing, which only became major issues in the 1990s, are effectively two key factors driving the development and diffusion of new technologies. Knowledge and finance condition the flow of inventions and the speed of diffusion of new technologies.

As a result, developing and putting to use the potential of new technologies has only been at the forefront of economic development for less than a decade. The 1980s were from this perspective the very first, preliminary 
phase of restructuring whereby the labour market and finance markets only gained some room for manœuvre in cutting through old, dominant linkages. This view of course fits the historians' general finding that transitions from one technological system to another takes time, as Freeman (1987) and David (1991) in particular stressed, and are accompanied by innumerabie institutional mismatches.

Yet, at the same time, despite the valuable insights, such historical comparisons do not allow one to infer that transitions will necessarily and always follow similar patterns. On the contrary, the specificities of each technological paradigm, the space and time in which it develops, all suggest that phasing and sequencing will differ. Consequently, one has to be careful when assessing what the new institutional matching will be, which countries will be leaders on the technological frontier and which will be followers. So far the 1990 s have shown a ranking in growth and technological performance even when we limit oneselves to the 'triad' which was not obvious from the start. The 1990s did show the comeback of the US economy at the frontier of the new economy. After the 1980s, when the US leadership appeared to become increasingly challenged by the abilities of some Asian countries to produce IT equipment, their capacity to make wide use of this equipment, combining the new computing and telecommunication potentials, and to develop, on the basis of this know-how, highly intensive knowledge-based activities, has undoubtedly restored the USA to the position of leader. Japan and Europe appear to lag somewhat behind.

But again this is by no means the end of the competition at the technological and economic frontier. The technological paradigm around the ICTs is itself the outcome of the internal speed of development ensured by the everincreasing storage capacities of semiconductors known as Moore's law (the storage capacity of semiconductors doubles every 18 months) and the constant upgrading of software that this implies, open to a lot of competition. There is intrinsic room for manouvre here. On top of that there are great potentials for learning how to use efficiently this equipment capacity in complex organizations. It follows that a club of countries remain active in the technological race, beyond the simple hierarchy that one might witness at some point in time, as today with respect to the USA. The weaknesses that one may observe in Europe or in Japan today in some leading technological activities have, in other words, to be seen in a dynamic perspective, allowing for new, unexpected learning potentials to emerge and abilities to diversify, thereby assuming technological leadership in some specific production fields and market niches.

This does not mean that we are unable to make any comparison and prospective assessment on the relative potential of countries to play a major role in the development of the current new technological system, and this 
volume contains a number of contributions which make such challenging assessments (see, for example, Chapter 1 and Chapter 14). But two lines of investigation have to be distinguished in order make a comparative assessment of the perspectives of technological development open to each country. One is 'diachronic' and has to do with the relative capacity of each national system of innovation to adjust to the challenge of internationalization. The other is more 'synchronic' and concentrates on the intrinsic properties of local adaptation to the new technological system.

The internationalization of national systems of innovation is from this perspective tridimensional. It is channelled by the internationalization of knowledge, of capital and of labour. A priori the internationalization of labour by means of migration plays a relatively small role in the process. The first phase of restructuring, in the 1980s, has even been marked by the relative absence of migration flows, with the exception of the USA, precisely at a time when the internationalization of capital was accelerated. Relatively little changed in that respect in the 1990s, but it has become clear that the migration of qualified labour, of professionals and scientists, will be an important issue for the near future. Already, at the core of the scientific labour force, the number of foreign students and academics is becoming important. It certainly is already the case in the USA, and European countries are starting to compete to attract foreign scientists (Mahroum, 1998).

As a matter of fact, at this level the issue is part of the increased internationalization of knowledge, which is a multidimensional phenomenon. Some knowledge is produced and developed from the start at an international level and circulates via international networks of academics and researchers (see here, for example, the typology of Archibugi and Michie, 1997). A structure like Internet clearly induces further, and expands, such dynamics. At another level, large business services are also major channels for technology transfers, along with all the transactions having a direct bearing on technology sales, from standard patents to all kind of franchising and intellectual property rights. This is also the case with the export of equipment goods, international transactions traditionally considered as passive vectors of technology transfers. Technology can by now be transferred by various means. Beyond this aspect of access to technology, the policy interest lies of course in the capacity of assimilation of each country. As stressed by Nelson and Pack (1999), the challenge of national systems of innovations is not so much to accumulate new technology equipment but to assimilate the technology and get to know how to use it comprehensively. In particular, the learning process may take longer in some countries than in others. Secondly, adjusting the old qualities of the national system of innovation may lead to the development of some niches more than others or to the retention of particular specializations. 
Therefore comparing the potential of different national systems of innovation is useful and particularly indicative of the kind of specialization fitting any given country. From this perspective, the contribution by Amable and Boyer to the present volume points to some of the major weaknesses of Europe's innovation capabilities but also hints at the potentials that can advantageously be put to use. Within a certain sub-set of countries, chances to catch up with some developments on the technological frontier, whatever the size of the country, are worth considering. The learning process by which countries acquire the know-how and knowledge in an open environment is from this perspective complex and composed of many alternative ways for countries having reached a certain level of development in terms of wealth and human capital.

Looking at the internationalization of capital and, more precisely, at the internationalization of the national system of financing, one can reach similar conclusions. National systems tend to adjust to the pressure of internationalization in a more or less direct and automatic fashion. Some countries may have to develop entirely new forms of interventions, quite different from old structures. This will take time and the lack of complementarity with the old system may lead to some oppositions between new and old set-ups. Japan is a good example of a country where the old national banking system finds it difficult to follow the new trends to develop risk venture capital induced by the search for short-term, higher profits.

But this comparison should not be confused with the more 'synchronic' perspective which takes into account the specific assets of countries as weli as the 'ideal-type' generic properties of the new system. For instance, the new financing system implicit in the new economic context is more open to risks, including some risk of a major systems crisis. However, it does not follow that, in this new context, countries which have gone some way towards this type of adjustment are more specifically prone to financial crises than-countries which have not done so. Freeman, whose contribution in this volume emphasizes the various aspects of the relative positions of financial systems in the triad, points quite rightly to the differences between the systems in dealing with risks. The US system appears in this comparison as highly risky and unsteady. Yet, beyond this observation, one has to account for the greater ability of the system to adjust precisely to higher risk levels. The chailenge is then to appreciate how far the USA has gone ahead in terms of risk management at all levels, and to what extent they eventually might have gone too far in that direction, taking too many or too huge risks to be dealt with even in a more sophisticated and more risk-monitoring economy.

In such international comparisons one has thus to take into account a 'synchronic' perspective which sufficiently appreciates evolutions in relation to the would-be characteristics of the new economic system. It is certainly an 
intrinsic feature of the so-called 'new economy' to be more open to risk taking, thus enlarging the spheres of productions and transactions. A real challenge is to assess the limits of this enlargement beyond which the economy is becoming truly unsteady and open to major crises. From this perspective, the present volume invites one to explore further this frontier; it clearly shows that international comparisons and prospective assessments have to be put in a dynamic setting explicitly allowing for interactions of structural and institutional change.

So far we have stressed some broad, qualitative and institutional changes having affected most developed economies in the field of technology and employment over the last two decades. The period, as we have argued, was itself clearly divided into two sub-periods and the concerns tied up with a new growth regime really only emerged in the more recent phase of the 1990s. How the institutional changes on which we have concentrated so far facilitate what we call structural and organizational change is, as we emphasized in the introduction to this book, a key determinant of the relationship between technology and employment. It is to those issues that we turn now.

\section{STRUCTURAL CHANGES AND ORGANIZATIONAL ISSUES}

Structural changes are here thought of as the ground in which institutional changes are somehow rooted, as well as constituting their soil. Structural changes are thus setting the scene for economic activities. This structural context is marked, in our view, by three interdependent changes. Two of these, internationalization and the diffusion of the new technological system centred upon ICTs, are well recognized and have already been central to our discussions in the previous section. The third dimension remains, at least in most economic analyses, often implicit: the current phase of tertiarization, with a significant rise in new 'business' service activities alongside the more long-term, gradual trend of tertiarization in developed economies associated with the growth of personal and social services.

Reviewing the dynamics of this third 'nexus' helps us to assess in a more explicit way the various trajectories of countries in the building up of their own brand of the new growth regime. This raises complex issues on the internal and external organization of firms, which in turn affects the dynamics of employment in many ways. It manifests itself, for instance, in terms of new relationships between firms and new skill requirements within firms. Many contributions in the present volume precisely address some of these issues. Caroli, in her survey, stressed how the change of technological system induced organizational changes marked not only by the national wage-labour 
institutional nexus but also by a general trend towards granting more responsibility to workers at lower levels of the hierarchy. Gatti, on the other hand, called attention to similar effects by modelling the microinstitutional context of firms and showing that relevant organizational choices were more important than the increased flexibility of labour markets. Finally, De Loo and Ziesemer tried to model the links between three aspects of structural change, namely trade (internationalization), technological change and labour supply.

We start here, though, with a recapitulation of stylized facts which orders somewhat the various findings of the book. We start with the present phase of tertiarization, keeping for the next section the key issue of labour supply and its determinants, such as changing demogtaphic conditions. ${ }^{1}$ We gave in the introduction some stylized facts regarding the new technological system centred on information and communication technologies. One feature is undoubtedly that it does represent only a small amount of the standard notion of installed fixed capital, as most of the financial investment that it corresponds to is intangible (software expenditures, development, training and organizational costs) and therefore difficult to estimate (see Sichel, 1997; Kendrick, 1994) and increasingly much larger than its tangible counterpart. Still one should not underestimate the tangible side of ICT diffusion, for at least three reasons. The first is that the growing capacity to store, to manipulate information and to communicate worldwide and instantaneously, changes the time and space dimensions of economic activities. The second reason is linked to the impetus given to all these tangible equipment flows by Moore's semiconductor performance law (the storage capacity of semiconductors doubles every 18 months) which constantly broadens the range of innovative applications. A third, and more ad hoc, reason is that the diffusion of tangible ICT equipment, whether it relates to the actual use of PCs or to the number of Internet connections, offers indicators of the diffusion process (see OECD, 1999). Such physical use and accumulation trends do not, of course, imply effective assimilation of efficient use. Misuses and inefficiency are also part of the diffusion of the new technological system.

It is clear that the present phase of the process of internationalization fuels further the diffusion of the new technical system, based on ICTs. ICTs can even be considered historically the first technical system, which diffuses, one way or another, so rapidly on a worldwide scale. Of course one has to clarify what is specific to the present phase of internationalization. It can be qualified as a phase of globalization, not so much because the intensity of trade and foreign direct investment (FDI) flows will have reached unprecedented levels - countries such as the UK, the Netherlands or Japan experienced similar levels of internationalization at the end of the 19th century - nevertheless, the fact that trade and FDI patterns now involve an unprecedented range of countries and concern a much more widely diversified range of 
products, with a particular importance given to the technologically more sophisticated products, is really specific to the current phase of globalization. The present phase of globalization is also characterized by the fact that most economic transactions now take place as part of strategies that account for international conditions and opportunities. This is made possible by the diffusion of information on international opportunities, as well as by the existence of intermediaries, whether in the form of international partnerships, through the internal organization of multinational firms, or via international networks of services. The large flows of information rapidly available on all sorts of topics, as well as the possibilities for cooperation with academics and other non-market institutions, clearly also contribute to the building up of these logistics of international mediation. The development of advanced telecommunications has closely accompanied and enabled this internationalization of firm strategies. Information networks have been gradually developed, slowly leading to the recent explosion of the Internet, which again offers a dramatically new potential for international transactions. This significant enlargement of the scope of actions may not necessarily appear in the balance of payments, as long as it does not lead to effective transactions. Still the new scope to act at international levels and its effects on national economies is a key feature of the present phase of globalization. It leads to a larger capacity for a larger number of (small) firms and even households to develop international transactions.

Central to the enlargement of the international reach of firms is the development of business and intermediary services with a global reach. This is linked to the phenomenon of the increasing tertiarization of economic activities, which has probably not been emphasized enough as a central element in the development of our economies. Tertiarization in a broad sense is not a new phenomenon, and the growth of the share of employment in the services sector follows a long historical trend, not altered by the relative slowdown in economic growth which has affected most developed economies since the mid-1970s. Still the tertiarization trend experienced over the last two decades has some distinctive features, the most marked of which is the unprecedented growth of business services. Their share in total employment rose from a few percentage points to more than 10 per cent today. The business and finance services sector constitutes a 'new' phenomenon, characteristic of a new fabric of relations between firms, and consists of a wide variety of specialized services to business (from audit and research labs to cleaning and surveying). These new service activities mix very diverse types of activities, some using highly qualified labour and others requiring low-qualified labour.

The development of a set of highly qualified service activities in many new market niches appears primarily linked to the diffusion of new information and communication technologies (ICTs). Some of these activities were in- 
strumental in developing a logistics which, together with the spread of large network services in communication, transport and distribution, further induced the enlargement of this global reach capability. On the other hand, the same activities also contributed strongly to the diffusion of the new technological system. In the first place they provided the core of professionals needed to maintain, assist and complement the diffusion of the new information and communication technologies (all business services linked to hardware and software activities). Secondly, they developed new sorts of activities, exploiting for individual firms the data-gathering possibilities of new ICTs in terms of data mining, treatment and fast communication of such increasingly valuable commercial information. The development of such expertise has been an important factor favouring a reshuffling in the internal organization of firms, their outsourcing practices and product turnover. It does not mean though that a new 'optimal' model of firm organization emerged in the process. The latter remains largely a learning process, influenced as much by local traditions and tastes as by the efficiency of local suppliers of qualified services. Thus Schettkat and Russo, in Chapter 4 of this book show that external uses of business services (as shown in input-output statistics) had only a small impact on the dynamics of productivity gains. Beyond the fact that the measures in real terms of these intermediate uses are rather uncertain, the fact that they developed strongly across the board of most countries does not help us to determine their efficiency effect, particularly over a period when productivity gains at the macroeconomic level did, if anything, slow down.

We thus stress the interdependence of a nexus of structural changes more or less common to all countries but difficult to assess in terms of the relative efficiency of the different country experiences. This nexus of transformation is consistent with the microeconomic transformation of activities described in Chapter 6 by Petit and Soete whereby the diffusion of ICTs was shown to enlarge the provisionability and content of both service and manufacturing activities alike.

Thus both the elaboration and diffusion of ICTs are channelled through all kinds of specialized and highly qualified business services (from software producing to all sorts of consultancy), which are at the same time large buyers of ICT equipment. Hence globalization or internationalization has largely drawn on and been enabled by telecommunication and computing facilities, as well as the appearance of business services provided by large multinational firms.

The interdependence of the three aspects of structural change outlined above and in Chapter 3 (see Table 3.3) calls for a multidimensional representation and perspective on the surrounding socioeconomic context. This can be represented as a triangular nexus of structural changes, as in Figure 16.1. The 


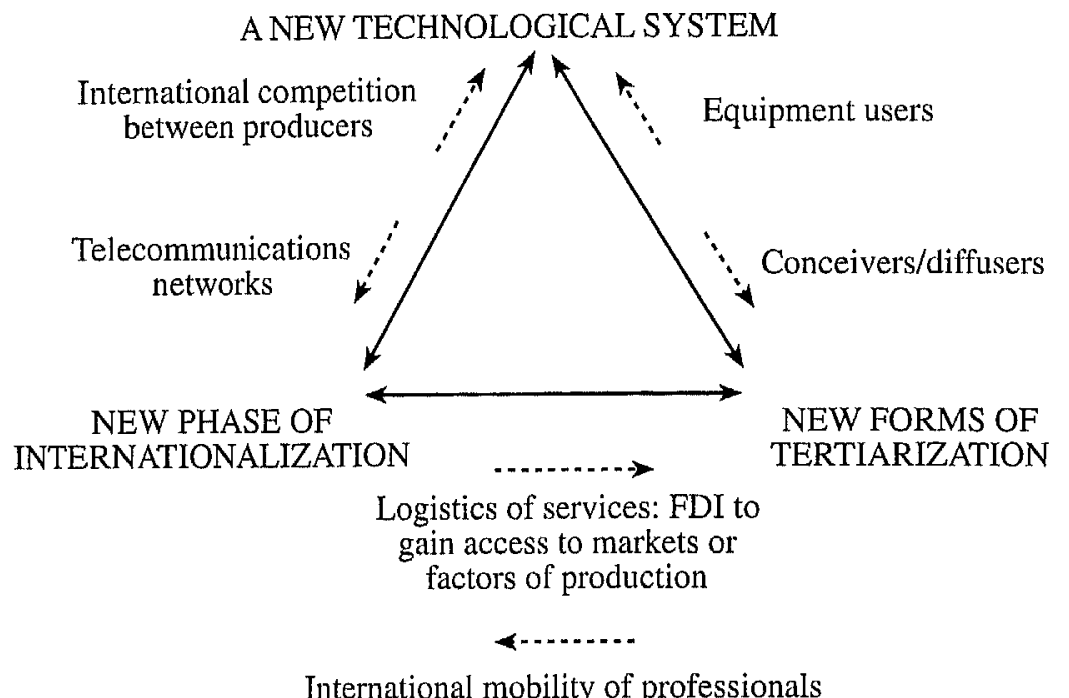

Figure 16.1 Three interdependent structural changes

figure illustrates the possible outcomes of the present period of trial and error, where economic agents (essentially firms, but also households) experiment in the form of more or less continuous reorganization in order to try to match the changes taking place. This multidimensional perspective on current structural change stresses the broad organizational challenges with which our economies are being confronted. It concerns firms, how they organize their work in-house or take advantage of external suppliers (especially services). It also concerns households, who can radically reorganize their domestic activities, following or favouring changes occurring at work or with regard to the services they use.

While the above appears more a necessary combination of structural changes, its links to total employment remain largely undetermined. Pianta, in Chapter 5 of the present volume, underlines the fact that innovative activities in manufacturing, because they have been more oriented towards process innovations than towards products innovations, have had no positive impact in Europe on employment. Conversely, Landesmann and Stehrer, in Chapter 7, stress that the late deindustrialization process in many continental European countries can account for the high unemployment observed in the 1980s. It manifested itself in lags in the adjustment of various productive processes with eventually persistent negative effects on structural unemployment. Beyond these structural mismatches, differences in total employment growth remain, by and large, unexplained. Schettkat and Russo in their contribution 
stress that manufacturing, augmented by the set of services that are carrying the reorganization of the production processes, cannot be considered as an engine of growth which could account for the overall growth rate of GDP and employment. The employment content of growth actually differs widely between countries. A good number of these differences are linked to the expansion of personal, social and community services, as emphasized extensively in the contributions to Part III of this book.

In effect, a steady growth of these services accompanied the development of the nexus of interdependent structural changes mentioned above. This, increasingly massive, component of employment, which benefited from the rise of public budgets in the $1950 \mathrm{~s}$ and $1960 \mathrm{~s}$, continued to grow over the period of slow growth of the 1980s and 1990s. It corresponds to a wide range of good and 'disadvantageous' jobs, and the combination and relative importance of sub-sectors in the field is very much country-specific. One could say that the pattern of services (business or community services) that we currently observe is very much path-dependent, based on services provided somewhere in the past on the basis of some specific initial conditions. This implies the type of welfare state that has prevailed in the immediate, postwar period and developed until recently (see Mjøset's contribution for a discussion of types of welfare states and their evolution).

Having analysed the main features of the differences in institutional and structural changes, we can now draw some conclusions on the trends observed so far. To complement our policy conclusions it will also be important to point to changes which have not yet occurred but are foreseeable in the years to come. They relate to demographic changes and the transformation of household 'services' once the impact of ICTs fully reaches them, whether domestically produced or provided by a public or private organization.

\section{GROWTH AND EMPLOYMENT: CONVERGENCE AND DIVERGENCE IN TIMES OF TRANSITION}

From a long-term perspective, the last 25 years have been characterized by the widespread slowdown of economic growth by comparison with the 'golden years' of capitalism that represented the 1950 s and 1960s. This stagnation followed a marked reduction in productivity gains which has been the centre of many academic, measurement and policy debates for the last 20 years. The productivity slowdown has been a widespread and general phenomenon across both countries and sectors. However, the rates of economic growth have been affected in very different ways, especially in the 1990s (see Table 16.2). On average, countries experienced a prolonged period of stagnation, but some countries did experience extensive economic growth (with growth of GDP 


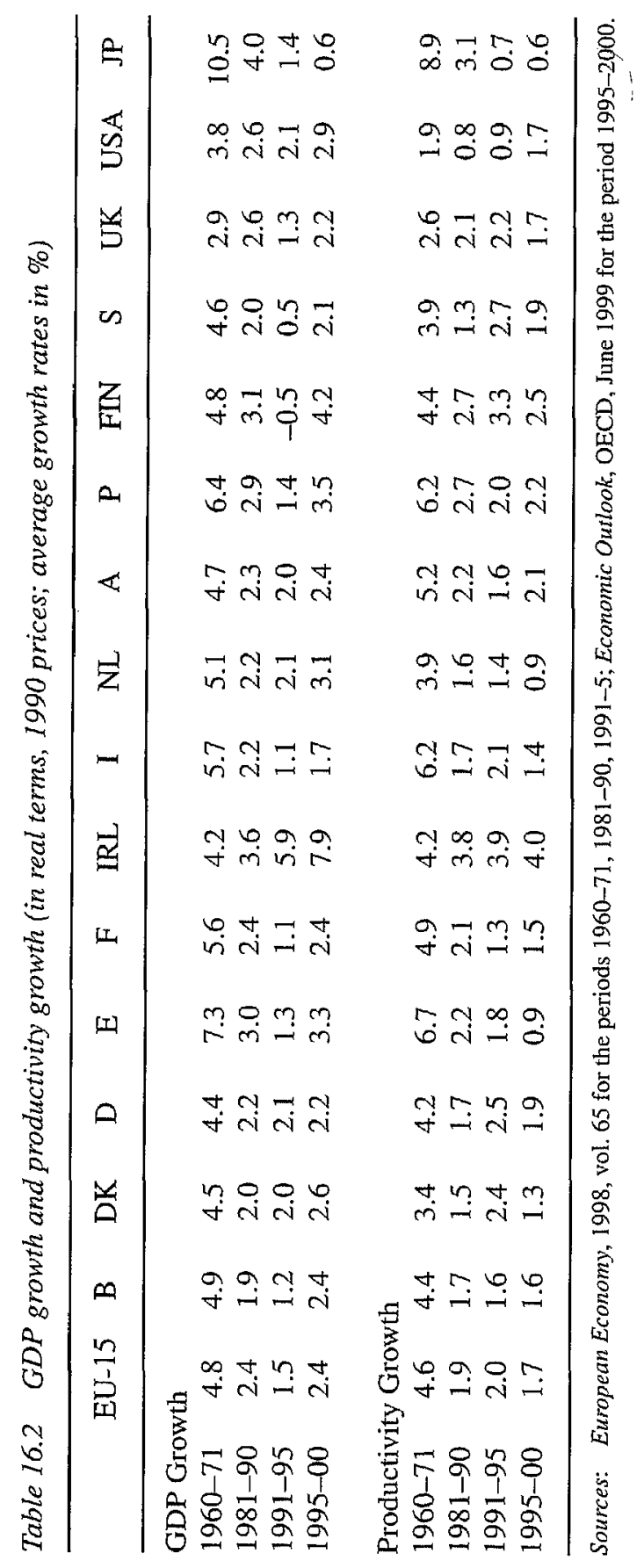


being accompanied by a similar growth in employment). This is in particular the case of the USA, which enjoyed a long period of sustained growth through the 1990s (unprecedented in peacetime, but slower than the long expansion period experienced during the Vietnam war), with until recently record low productivity growth gains (measured in terms of GDP per person employed) in comparison with the European countries and Japan.

The three European countries which enjoyed a more rapid economic growth rate in the 1990s benefited from specific opportunities (natural resources, as in the case of Norway, or a rapidly growing logistical base for international transactions, as in the case of Ireland and the Netherlands). Whether they are heralding a general resumption of productivity growth remains an open question. The recent increase in productivity gains in the USA, where GDP per person employed jumped from 1 per cent over the period $1989-95$ to 2.5 per cent over the years $1996-9$, has also to be treated with cantion. The major fact, as underlined in the contribution by Petit in this volume, is that for the last two decades the productivity gains in the USA have been increasingly differentiated between manufacturing and services. Somehow productivity grew at a more rapid rate in sectors heavily investing but losing jobs, while in service sectors, where employment has increased dramatically, investment remained well below the average growth rate and the already weak improvements in productivity growth further slowed down. Even the recent rise in manufacturing productivity follows an upwards move in investment (see Brender and Pisani, 1999). In 1997, 1998 and 1999, for the first time in 30 years, total investment in the USA was higher than in Europe (see Muldur, 1999). The real effect on productivity of the diffusion of the new technological system is hence still in its infancy stages, having only boosted investment in some sectors (with no clear rise in the autonomous trend of technical change), even in a country where the new technologies and the accumulation of knowledge have transformed, and continue to transform, the organization of production and markets, and in particular the distribution of goods and services. The figure is even less clear for the large European countries where productivity gains remain low and where the experience of the last two decades has not, as yet, led to the distinguishing of a 'model country' which, as measured in terms of productivity gains, would have done much better than the other European countries in taking advantage of the new technologies and knowledge accumulated to spur growth and employment. The experience of many of the small European countries (Austria, Denmark, Finland, Ireland, the Netherlands, Norway, Portugal, Sweden) suggests, on the other hand, a variety of models, some of which appear related to the effective exploitation of some comparative advantage in relation to a particular feature of the new technologies, while others are specific to other characteristics of country specialization and locational advantage. 
Nevertheless, what we observed in the area of institutional and structural change suggests that, after two decades of trial and error, the preliminary conditions for a change towards a new growth regime are now in place in most countries. The first decade saw a more or less drastic adjustment of practices on the labour markets, while the 1990s were witnessing a difficult process of reorganizing the finance and network-service sectors while increasing the role of qualified labour in production processes. What then could be the future of technology and employment in Europe? This future is, in our view, determined by the answers that one can give to a set of interrelated questions.

The first question bears on the relation between Europe and the USA. Can a 'New Economy' model diffuse to Europe? We more or less acknowledged in our prospective exercise that a new economy has been developing in the USA, but that its development was a long and risky process: long to emerge, when measured in terms of productivity growth, and risky because of the highly speculative nature of many of the new business ventures, and especially the financial ones. We should add that the extensive US boom in the 1990 s was accompanied by a large increase in employment in services of both types, qualified and unqualified (see Chapter 6 in this volume). A lot of this last category of jobs in large metropoles fell into the category of working poor. The widening of the distribution of real wages and earnings since the 1970 s has been spectacular. For full-time male workers, the average wage of the Iast 25 th percentile was back to its 1960 level, while for the 75 th percentile the average wage was 50 per cent above their 1960 level in real terms (see Ellwood, 1999). This is a specific US feature of whatever would be a New Economic Growth Regime that could diffuse to European countries. Another specific US feature is tied to the hegemonic position that gave the USA the technological and intellectual property 'appropriation' leadership forged in the course of the last two decades. The question is how the catching up of Europe and other countries, which over the 1990s experienced some widening of the gap, can take place and to what sharing of rents of innovation it will lead. The extent of restructuring still under way in most European countries and in particular in Germany is such that this remains an open question. So far the USA has enjoyed the bulk of the rents of innovation in the booming intangible new industries, with only a few exceptions (mobile telephony, smart cards, digital television). Norms, standards and regulations established in the meantime tend to strengthen this position, facilitating the huge US deficit in the external trade of standard goods. It goes beyond the objective of this book to assess in more detail the sustainability of such unbalanced growth and how Europe's catching up could take place in this setting. But some elements of the various analyses presented here specify the conditions for European countries to make the most of the opportunities that are available. 
As we have already indicated above, not all European countries are in the same position and a dividing line could well separate Europe in two according to the ability of each country to catch up with the technology leader. Not only did European countries start from various levels of development in terms of GDP per head (or persons employed) but the period of transition here under review, with its marked slowdown in overall economic growth, has also experienced a relative slowdown in the process of catching up. When a new technological system is building up and diffusing, it has a double impact on the standard catching-up process, which basically relies on the lower unit costs of the lagging country and its ability to transfer technologies by means of the acquisition of equipment goods.

In a first phase the change to a new technological system occurs through a period of stagnation where the pressure on price differentials is lowered, which in turn reduces the competitive pressure of catching-up countries. In a second phase the transition towards a new technological system is illustrated in the fact that the leading countries are in a position to shape the development of the new system to their own advantage, which in turn reduces the transferability of the new technologies. Agglomeration effects, which are particularly active in the development of the current new technological system, changing in depth the time and space dimension of economic activities, re-enforce the advantage of the leading countries. They may also create specific comparative advantages for some catching-up countries in a strategic position in the diffusion network of the new technological system. The extraordinary expansion of Ireland over the last decade is an example of such an opportunity, but, by and large, under the two effects mentioned above, the growth convergence between European countries and the USA, the technological leading country in the new paradigm, has slowed down over the last decade.

The countries which have been the least affected by this slowdown may seem in the best position to resume the catching-up process. But the process of EU trade convergence may well have itself deeply transformed the process and capacity of European countries to resume catching up growth in new intangible goods and services. The recent collective work on European competitiveness edited by Fagerberg et al. (1999) suresses the particular importance of non-price competitiveness in the trade relations of Europe. In our analytical interpretation, this would imply that technology transfer in a world where non-price factors are playing a larger role will not occur to the same extent through the simple acquisition of equipment goods. More important will be the exchange of intangibles, foreign investment and various formal and informal exchanges of codified knowledge and, last but not least, the migration of highly skilled personnel (tacit knowledge). Chesnais et al. (1999) insist on the particular role played by multinationals from the leading countries in 
these processes of technology transfer which condition the diffusion of a new technological system among the follower countries. The development of FDI within the world of developed economies after the mid-1980s is a sign of this technology transfer. However, such traditional 'physical' investment technology transfer channels have a strong sectoral dimension, which limits the learning potential of the transfers.

A potential advantage in this respect is that, contrary to what was experienced in the USA at the beginning of the 20th century, the construction of a united Europe has not led to an extensive specialization of and between countries. The industrial structure of European economies remains diversified (see CGP, 1999). Surprisingly, maybe, this might well represent today a positive factor for a more 'fully fledged access' to the new technological system across Europe and across sectors, and might thereby facilitate innovative adjustment, if only by means of fertilizing spillovers across countries and sectors. The development of business services will help in this adjustment process even through affiliates of foreign, non-European firms, which turn out to be important vectors of technology transfer.

The overriding, present reality remains of course that European countries did not catch up with the development of the core of ICT industries as well as did the USA or Japan. It may be a matter of time, but the importance of the particular ICT production lag may also have been exaggerated if countries prove able to be leaders in sectors using these ICTs and if these technologies are accessible worldwide. A diversity, which may effectively limit the overall capacity that European countries could develop to catch up and be active promoters on the technological frontier, has to do with the national structures of the deregulated large network industries. The relative heterogeneity in the rules and regulating agencies of the old network services, whether finance or telecommunications, limits advantages to be gained at the European Union level. In particular, it limits the synergies and joint ventures that European companies can expect within the large economic space of an integrated Europe and consequently reduces their room for manœuvre in their worldwide strategic operations. It also limits the possibility for countries lagging behind to catch up.

With these caveats in mind, we would conclude that a good majority of countries in Europe can have access to the new technnlogies. The question behind some Euro-pessimism bears not so much on the capacity of European countries to gain access to the new technologies, but more on their capacity to take advantage of these technologies in terms of economic growth and employment. For this to occur, countries have not only to master the new technologies, but also, as Pianta argues in Chapter 5, to be able to turn them into product innovations. This lack of a crucial capability can also be linked to the delay with which venture capital developed in Europe. It expanded 
rapidly in the USA in the 1980s, giving birth to a great number of new, today very large, worldwide companies (Microsoft, Federal Express, Digital Equipment, Intel, Cisco and so on), and only developed in the late 1990s in Europe. Again, as with the other large network intermediate services, the segmentation in Europe has hampered their boosting effect.

The above does not mean that all European countries will have an even access to the new technologies. A set of less developed countries will obviously meet some difficulty, as underlined in this catching-up process. They risk being left behind, with a growing gap, if some policy to support the transfer of technology is not given a fair priority on the agenda (and all the more so after the enlargement of Europe by eastern countries). It may also be the case that some regions within countries, with large access and mastering of new technologies, will still need some support for their own development. In effect, if countries within Europe remained diversified, they also developed a tendency towards regional specialization which may lead to some regions forging ahead and others lagging behind. An adequate regional policy will thus certainly remain necessary, but also will require increased and consistent efforts to match what is the real challenge of the new model, that is its content in terms of economic growth and employment.

If a large share of economic growth can follow from the competitiveness of a developed economy in most activities, we saw that employment was much more dependent on the organization of community, social and personal services. Again this organization is closely tied to the choice of welfare state retained by each economy earlier on (as clearly indicated by Scharf, 1997). In Chapter 15, Mjøset underlines the different kinds of welfare states which exist in Europe according to the various roles given to the family, to public services or to market services in caring for our health, education and resources at all ages. These welfare states already underwent some transformations when going through the period of slow growth and mass unemployment. The search for a greater flexibility of labour markets led to some adjustments in their rules and transfers, which can be globally qualified as a turn towards systems keener to preserve incentives to work for all those fit to work (a 'workfare' orientation, to refer to the UK model, which corresponds also to the changes experienced in the USA).

Beyond this transformation, closely linked to the search for some labour market flexibility, demographic factors, namely the increasing effects of the reduction in birth rates across Europe, are challenging even more radically reduction in birth rates across Europe, are challenging even melfare systems. Esping-Andersen (1999) and Mjøset, in his contribution to this volume, strongly underline that ageing of European populations is a major issue of our present time. This challenge is being largely debated in our societies with regard to the growing question of the future of most pension schemes. There is a pressure to shift to pension funds systems which 
would not be as vulnerable to drops in participation rates as are the present systems.

We contend that the challenge to the whole organization of the welfare systems is of even greater importance than it appears through this issue of retirement schemes. In effect they are of crucial importance in promoting a reorganization of the whole pattern of personal and collective services which is determinant not only for employment, as we saw, but also for a consistent contribution to economic growth. In other words, the changes in the patterns of household consumption and ways of life which are at the root of fundamental transformations of the welfare systems may, or may not, accordingly, be the supportive missing link to the full expansion of the so-called 'New Economy'. This applies equally to the USA, where the expected rise of a real New Economy may well be marred by too low productivity gains in large service industries. Welfare needs can be provided in many ways, using more or less qualified jobs in marketed or public services. The extent and quality of the coverage vary. Discussions on welfare states address the issue rather indirectly when looking at the propensity of each welfare system to favour or not the employment of low-qualified labour. International comparisons of welfare states thus oppose an Anglo-Saxon model, where low-paid menial services can be developed for such social needs as family care, with a Scandinavian model where similar services are provided by numerous public service schemes. What is at stake at present is precisely the types of services and the ways of life that can be developed with the new technologies and the knowledge that they can mobilize. Indeed, this is a huge programme of redefinition of family care, old age organizations and leisure, not to speak of the huge field of education and health systems.

We have already noted that, strangely enough, most of the signs of the new economy retained in the public debates referred to changes in the supply side of the economy, namely, how new relations to technology and finance will change the production processes. Our contribution in Chapter 6 of this book underlined the potential of the role of demand in a new growth pattern. Therefore a key issue in the transformation of welfare states lies in their ability to adjust the old model (choices of welfare systems are so ethically essential that one cannot imagine countries shifting entirely away from their welfare system with the respective importance it gives to families, public or market provisions of services) to new patterns in accordance with the future of their demography and with patterns of consumption and ways of life, making the best of the new technologies and knowledge to increase their achievements. Such a drive enriching the provision of welfare services is also bound to have cumulative effects on economic growth, while learning processes ensure that the best practices of user-producer relations diffuse throughout the economy. The challenge to this transformation on the demand 
side is enormous. It is obviously a dimension which has been so far lacking in the US experience of the new model, where the long path of slow growth has generated increases in poverty and inequalities which are not only a failure in terms of welfare but also very likely an important limitation in the future to a full-size recovery of economic growth and GDP per head.

But here again the challenge is quite different from one European country to the other, if only because the demographic futures are quite different. Table 16.3 illustrates the large differences among European countries in both the age structure of the population and the natural rate of growth of the population. It points to the likelihood that labour market situations will increasingly start to differ in the relatively near future. The present low rate of natural growth of the population and the rapid ageing in most member countries may well transform in a decade or so the situation of high unemployment that we now have in Europe into one of low unemployment on average, wi th some countries experiencing labour shortages and trying to increase the flow of immigration. How countries will ultimately take this turn depends on the type of growth trajectory chosen, and in particular on the favoured adjustment of their welfare system, but also on their internal political situation after more than two decades of slow growth and unemployment.

In redefining models of consumption, access to large systems of education, health and leisure, deeply transformed by the new technologies and knowledge (as suggested in Petit and Soete, 1997) the local dimension will certainly also play a role. It is a well-known paradox of modern changes to transform time and space dimensions in ways which re-enforce local ties. Weak social local networks can be strengthened by the use of these technologies and knowledge, which allow in turn local market and non-market organ i zations to reap the benefits of synergies in connecting with large networks of services and telecommunications and thus to extend their reach worldwide.

From such a perspective the question of employment and technology in Europe in the years to come is highly contingent on the demographic situations on the one side and on the ability to develop a fully fledged provision of business, intermediate and personal services on the other. This presses for highly differentiated structural policies. The next section recalls these various policies, linking them to the successive issues we have raised as parts of the determination of future economic growth and employment in Europe.

\section{POLICY PERSPECTIVES IN A DIVERSE EUROPE}

At this stage the general policy perspectives for the various European countries can be broadly indicated. They are centred upon the set of institutional and structural changes that we stressed above taking into account their link- 


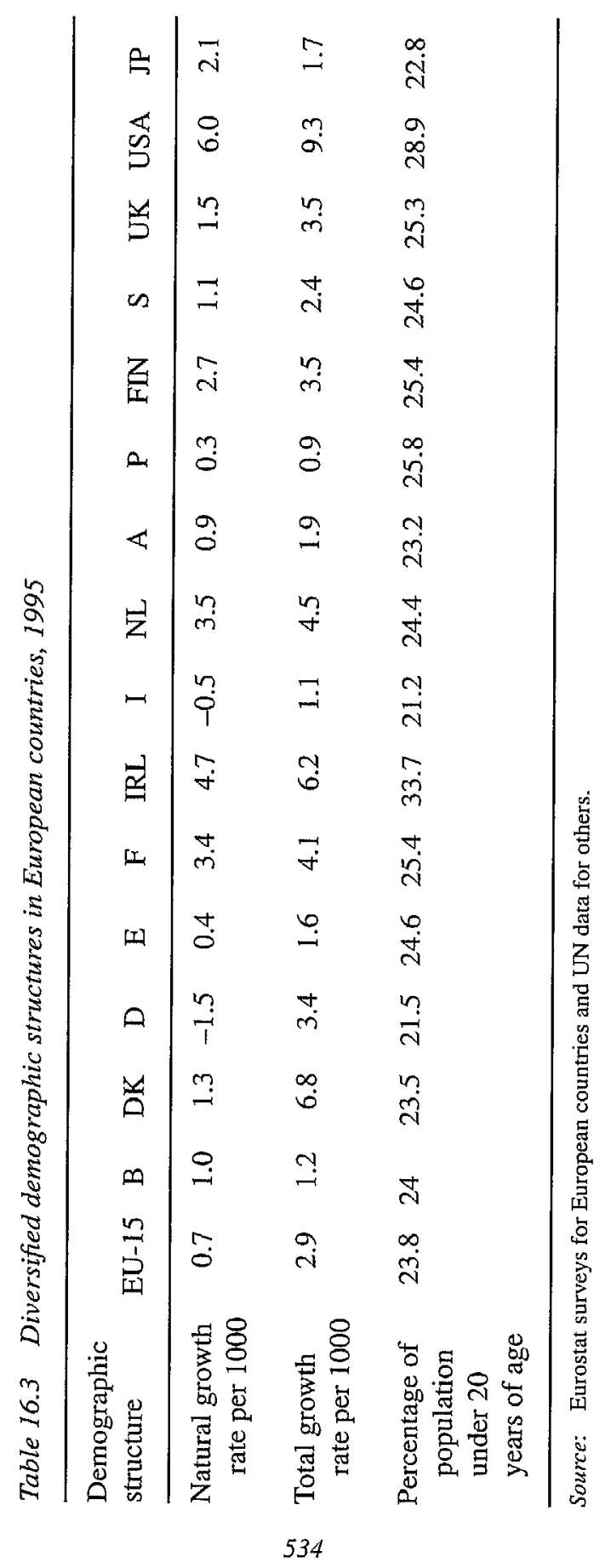


ages with the growth regime. Figure 16.2 lists these various links ats they have been successively presented in the above sections. The line of argumentation is quite similar for each country but the policy implications turn out to be very country-specific as national policies have to take fully into account the characteristics of each country in terms of wage-labour relationships and services organization. To what extent a European Union policy can help these diverse national structural policies is therefore a central question.

Three areas of structural policies can help in adjusting the European countries to the new conditions of growth and employment: first, policies with respect to labour markets, second with respect to intermediate large network services, and third with respect to welfare systems. These three fields are largely interacting. Actions on the labour markets are obviously linked with interventions on the welfare system; conversely, the forms of actions in these two fields are conditioned by the logistics of intermediate services that alre available, whether it is to support local synergies or to facilitate learning processes. Policy interventions should thus take into account these interdependencies when they try to respond to the two basic challenges of (a) ensuring the competitiveness of economies increasingly exposed to external competition, and (b) ensuring a full employment of the labour force, ats conventionally defined, in accordance with demographic conditions.

We have already stressed that competitiveness does not imply that the full employment objective will be reached; reciprocally, full employment does not ensure competitiveness, even if in both cases one without the other constitutes an unstable situation. The increasing internationalization of the economies has led in the last two decades to priority being given $10 \mathrm{com}-$ petitiveness. Policy interventions on labour markets in Europe, in the lirst half of the 1980s, focused on the objective of labour market flexibility to accompany the restructuring of manufacturing industries. Deindustrialization has been facilitated in various ways by this increased flexibility. It allowed countries to reallocate their labour force to sectors and niches less exposed to external competition. This restructuring also gave more importance to activities the competitiveness of which relied more on non-price factors. It contributed to shifting the focus of structural policies towards education and training.

This in turn raised in the 1990s two seemingly separate issues: what are the skills needed for such new competitiveness and how to employ the unskilled? On the first question experience has highlighted the fact that the skills required combine formal education, on-the-job training and out-of-work personal experiences. This last factor gained in importance, something which can be expected in a transition period, but also points to the need to restructure the process of training and education along lines of lifelong training schemes, which alternate work experience and diversified training programmes. These 


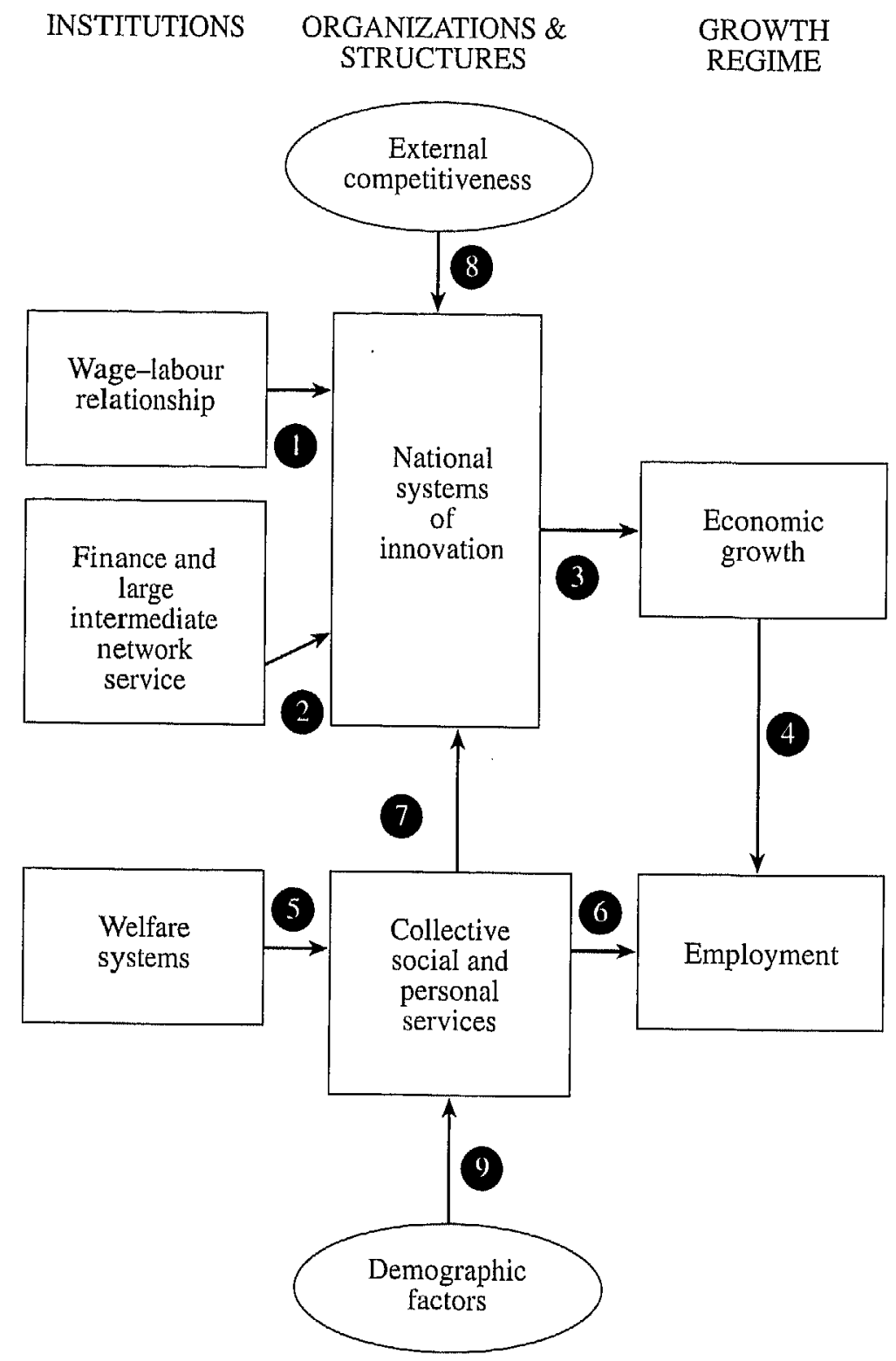

Figure 16.2 Employment and growth: the main issues 
'old' recipes have so far rarely been put into practice, the new context is now more favourable to their implementation. European policies can help in launching international schemes in human capital formation and also in setting norms and models of reference, all of which appear necessary and very useful, but the bulk of the effort remains with the individual member countries. A primary condition for the success of these national policies lies in their link with the structural policies implemented in the other areas and especially in the reform of welfare systems with the reorganization of the nexus of community, social and personal services that it implies.

Many contributions to this volume stress the fact that employment in these services was clearly making the difference in the levels of participation rate, whether countries were achieving full employment or not. Furthermore, this was even more the case after the restructuring of manufacturing industries when employment in manufacturing tended to reduce its demand for unskilled labour. This direct employment effect is illustrated in Figure 16.2 by arrow number 6 . The magnitude of employment in these services is particularly great, either when there is a fully fledged public provision, as in the Scandinavian countries, or when the labour markets are so 'flexible', with no minimum wage and an increasing number of working poor, leading to the provision of a wide range of 'market services'. Most of the continental European countries display an organization of these community, social and personal services which appears in some way a mix of the two schemes. These organizations stem from the various types of welfare systems developed in different European countries. As the characteristics of these systems mainly depend on the relative role given to the family, the public sector or the market in the provision of basic care, and as one should not expect rapid changes in the hierarchy of values which are grounding the overall organization of social and personal services in each country, it can be changed only in an incremental way (as underlined in Esping-Andersen, 1999). This explains why most continental European countries experienced mass unemployment despite their past commitment to full employment, and only slowly adjusted their pattern of service provision.

The experience of the USA, however, does show how incremental moves may end up with a widely transformed system of income transfer. It has not been noticed sufficiently when assessing the US experience that the US welfare system has been remarkably transformed. The cuts in welfare of the 1970 s and 1980s forced more people to work (an extraordinary rise in participation rates) and led to a rise in wage and earning inequality and in the number of working poor. This pressure was finally countered in the 1990 s by the implementation of various negative income tax mechanisms, raising the federal spending on low-income families (not on welfare) from six billion dollars in 1984 to 52 billion dollars in 1999. As we have seen, this redistribu- 
tion was relatively unrelated to the emergence of the 'New Economy'; it might, however, create the conditions for rapid take-off.

It is our strong contention that a deeper change of the nexus of social and personal services is also needed in Europe, which would take advantage of the new technologies and of the vast amount of 'codified' knowledge accumulated. The changes in health systems, in education, as well as in leisure and work organization, that are likely to emerge will strongly influence the way people spend their time throughout their lives. Moreover, the direction of the changes will clearly be influenced by the specific demographic conditions of each country. It could lead to extensive reorganization of the welfare system and of citizens' way of life - the more so if these changes can be presented as some kind of 'new deal'. The impetus to growth from such a transformation is broadly indicated in Figure 16.2 by means of arrow 7.

The bulk of local European experiences that have emerged over the last two decades suggest that such a view is not too utopian. But to consolidate and enlarge such commitments at some national or regional level also requires the support of adequate logistics of intermediation, whether in finance, communications, transport or in specialized business services. A balance has to be found between the adequacy of these supports of specific national needs and the advantages brought by regional harmonization of these logistics. In all cases a real effort has to be made so as to give full political priority in Europe to these issues of large social change. So far the 'New Economy' has been much driven by expectations of the role of technology, mainly implemented by an 'elite' of symbolic professionals, to use Reich's term, and officials, with a much more narrow perception by those who have experienced more hardship in the meantime. Basically, to live up to its promises the 'New Economy', still has to expand its perspectives to the social realm in a much more explicitly debated and enriched form.

\section{NOTE}

1. One reason for doing this is that a result common to many chapters in this book is the apparent delinking between an overall growth regime centred on the three structural changes mentioned above and a future determination of overall employment and labour supply which increasingly also involves other variables, and particularly demographic variables. At this final stage from which policies have to take their macroeconomic perspective, the position of European countries differs strongly and imposes in the end a quice differentiated policy diagnosis. 


\section{REFERENCES}

Archibugi, D. and J. Michie (1995), 'The Globalisation of Technology: a New Taxonomy', Cambridge Journal of Economics, 19, 121-40.

Archibugi, D. and J. Michie (1997), 'Technological Globalisation or National Systems of Innovation', in D. Archibugi and J. Michie (eds), Technology, Globalisation and Economic Performance, Cambridge: Cambridge University Press.

Brender, A. and F. Pisani (1999), Le nouvel âge de l'économie américaine, Paris: Economica.

CGP (1999), Géographie Econonique de L'Europe, Rapport du Commissariat Général du Plan, Paris: Economica.

Chesnais, F., G. Ietto-Gillies and R. Simonetti (1999), European Integration and Global Corporate Strategies, London: Routledge.

David, P. (1991), 'Computer and Dynamo: The Modern Productivity Paradox in a Not-too-distant Mirror', American Economic Review, 80 (2).

Ellwood, D.T. (1999), 'The Plight of the Working Poor', Children Roundtable Report, no. 2, November, Brookings Institution.

Esping-Andersen, G. (1999), Social Foundations of Postindustrial Economies, Oxford: Oxford University Press.

Fagerberg, J., P. Guerrieri and B. Verspagen (eds) (1999), The Economic Challenge for Europe: Adapting to Innovation-based Growth, Cheltenham, UK and Northampton, MA, USA: Edward Elgar.

Freeman, C. (1987), 'Le défi des nouvelles technologies', Interdépendance et coopération dans le monde de demáain, $\mathrm{OECD}$.

Goux, D. and E. Maurin (1996), 'Changes in the Demand for Labour in France', STI Review, no. $18, \mathrm{OECD}$, Paris.

Heilbroner, R. and W. Milberg (1995), The Crisis of Vision in Modern Economic Thought, Cambridge: Cambridge University Press.

Kendrick, J. (1994), 'Total Capital and Economic Growth', Atlantic Economic Jourinal, 22(1), March, 1-18.

Mahroum, S. (1998), 'L'Europe et le défi de I'exode des cerveaux', The IPTS Report, no. 29 , November, Seville.

Muldur, U. (1999), 'L'allocation des capitaux dans le processus global d'innovation est-elle optimale?', note DGXII-EC, presented to the Conseil d'Analyse Economique, Paris.

Nelson, R. and H. Pack (1999), 'The Asian Miracle and Modern Growth Theory', Economic Joumal, 109(457), July.

OECD (1995a), Jobs Study. Taxation, Employment and Unemployment, Paris: OECD. OECD (1995b), National Systems for Financing Innovation, Paris: OECD.

OECD (1996a), 'Technology, Productivity and Job Creation', vol. 2, Analytical Report.

OECD (1996b), 'Ageing in OECD countries. A critical policy challenge', Social Policy Studies, no. 20, Paris: OECD.

OECD (1997), 'Literacy Skills for the Knowledge Society', in Cooperation with human resources development Canada, Paris.

OECD (1999), Science, Technology and Industry Scoreboard: Benchmarking knowledge-based economies, Paris: OECD.

Petit, P. and L. Soete (1997), 'Is a Biased Technological Change Fuelling Dualism?', working paper, December, CEPREMAP, Paris. 
Scharpf, Fritz W. (1997), 'Combating Unemployment in Continental Europe', EUI, Florence, R. Schuman Centre, Policy Papers, RSC, no. 97/3.

Sichel, D. (1997), The Computer Revolution: an Economic Perspective, Washington, DC: Brookings Institution Press.

Vendramin, P. and G. Valenduc (1999), 'L'avenir du travail dans la société de l'information', FTU, Namur, FEC Brussels, June. 